every two cats. While in quarantine, animals are kept isolated and dogs are exercised separately. In these conditions, it is difficult to see how cross-infection could occur.

In an island free from rabies, the possibility of illegal importation must be reckoned with. Since 1919, more than 77,000 animals have been quarantined, and of these only thirty-two dogs and one leopard have gone rabid. On a large continent where the virus has infected wild life, however, border controls are clearly insufficient. Foxes in particular can transmit rabies very quickly from one country to another, and can spread the disease to domestic animals, evading all measures to keep dogs apart from one another.

This is what has happened in Europe during the last twenty years. Although most countries now require animals to be vaccinated before they are imported, the incidence of rabies has still increased. In West Germany, for example, the number of known cases rose from 1,400 in 1954 to 3,700 in 1966 , but up to two-thirds of these each year were among foxes. Dogs accounted for only about 5 per cent of the total. One measure widely used has been to vaccinate all dogs living within 20 to $40 \mathrm{~km}$ of a frontier with an area where rabies is in the natural environment, but the result is reduction rather than eradication.

The question arising from the British cases is whether six months' quarantine is long enough. Two dogs died after being in the country for about six months, and in any case the incubation period is notoriously uncertain. The virus can also be carried without any symptoms appearing. On the other hand, it has not yet been proved that the cases were unconnected. All dogs released from the relevant block of the Folkestone kennels since July are now under restriction and can only be exercised if muzzled and on a lead, so that if rabies has spread among them it will at least be contained.

\section{PROCESS PLANT}

\section{loy through Strength}

THe view that the British process plant industry should be organized in larger units is the dominating theme of the report of the expert committee which has been investigating the industry for the Ministry of Technology (HMSO, $3 s 6 d$ ). The report was promptly blessed by Mr Anthony Wedgwood Benn, the Minister of Technology, when it appeared this week. Mr Benn said that he had already met the Central Electricity Board, the Gas Council and three large industrial companies to discuss some of the implications.

The process plant industry has been an object of public sympathy ever since the exceptional demand for process plant equipment in the period centred on 1966 showed up the inadequacy of the plant manufacturers. One of the obvious difficulties, repeatedly referred to in the report, is that most of the manufacturers are comparatively small, with an annual turnover of between $£ 0.25$ and $£ 1.5$ million. But the Expert Committee also complains that there is too little coordination between users, contractors and manufacturers, that the larger process industries and particularly the large chemical companies have left the manufacturers and contractors behind technologically, that the plant manufacturers are by comparison poorly managed and unspecialized, and that both contractors and plant manufacturers are too small to have made headway in "breaking the virtual monopoly" of American contractors in the oil refinery business.

The Expert Committee advocates the familiar doctrine of rationalization as a cure. The Industrial Reorganization Corporation is urged to help bring about mergers, but the committee also asks that "the boards of leading companies in each sector of the plant manufacturing industries should urgently consider ... how to bring about the emergence of a small number of more efficient larger groupings deploying greater resources". One of the objectives, it says, should be to create a financial base large enough to support a meaningful programme of research and development. Another should be to recruit skilled and modern managers. The same recipe is offered the process plant contractors. They, too, should merge and, with the manufacturers, should pay attention to the need for better quality and more rapid delivery of raw materials, particularly special steels. As a spur to all concerned, the Expert Committee urges that nationalized industries and the larger users of process plant should make more use of their power as large buyers to encourage "the better and more forward looking manufacturers and to squeeze out the poorer ones".

This may be recognized as an echo of the present government's election manifesto in 1964, but the Expert Committee comes out against a state supported industry. On the other hand, the committee does consider that the process plant manufacturers and contractors could usefully link up with organizations abroad. The Ministry of Technology is told that useful work might be done by providing risk insurance for promoting commercial uses of new plant and processes. Coming as it does on the heels of several reports of the Working Party sponsored by the old Department of Economic Affairs, the new document should at least convince the industry that something needs to be done.

\section{PARTICLE ACCELERATORS}

\section{All Set for CERN Decision}

THe decision by the French Government last week to confirm its earlier commitment to the CERN $300 \mathrm{GeV}$ accelerator makes it almost certain that the council of CERN will finally decide to go ahead with the project when it next meets on December 18. French participation had been cast in doubt by the decision of the British Government in 1967 not to participate. Now France joins Austria, Belgium, Italy, West Germany and Switzerland among those faithful to the accelerator.

If the $300 \mathrm{GeV}$ project is ratified next month, the CERN council will have five sites to choose from, one in each of the participating countries except Switzerland. The accelerator is expected to take eight years to build at a cost at 1969 prices of 1,431 million Swiss francs (about $£ 140$ million). Of this, SFr 934 million will be spent on the accelerator itself, SFr 288 million on laboratories and services and SFr 209 million on preparatory experiments. The largest contributions will be from West Germany (36 per cent) and France (30 per cent).

If the project goes ahead, the British government will no doubt come under renewed pressure to join. The financial contributions for the first two years 
would be very small, as the table shows, and the only penalty for joining late would be the exclusion of a British site for the accelerator. (By all accounts, the piece of land originally suggested for this purpose in East Anglia would not have passed the clinical examination to which the other sites have been subjected.) If, on the other hand, the CERN council fails to reach a decision next month, a further postponement would place the project so far behind the American $200 \mathrm{GeV}$ accelerator at Batavia, Illinois, that it might even bc reluctantly abandoned.

Table 1. cost of $300 \mathrm{GeV}$ accelerator (millions of Swiss francs at 1969 prices)

$\begin{array}{cr}\text { Year } & \text { Cost } \\ 1 & 16 \\ 2 & 50 \\ 3 & 140 \\ 4 & 220 \\ 5 & 235 \\ 6 & 250 \\ 7 & 260 \\ 8 & 260 \\ \text { Total } & 1,431\end{array}$

\section{ENGINEERING MANPOWER}

\section{Call to Action}

LORD JACKson OF Burnley (lately Sir Willis Jackson) had some harsh words for the engineering institutions and the senior engineering staff at universities when he gave the first Willis Jackson lecture last week to commemorate the golden jubilec of the British Association for Commercial and Technical Education. Speaking on the problems of engineering manpower, he said that the engineering institutions have not been pulling their weight in instilling a sense of social responsibility in the junior members of the profession, and many engineering lecturers are far too fond of their ivory towers. "There are so many engineering teachers who are antipathetic to activitics other than research," he said; "in particular towards the productive industries. This causes me great concern."

On the shortage of engineering manpower, Lord Jackson, who is the chairman of the Committee on Manpower Resources and president of the newly formed Institute of Manpower Studies, said that it is more important to train people for the right job than simply to worry about manpower shortage in numerical terms. For one thing, graduate output is growing faster than its supporting manpower, and peoplc will end up doing jobs for which they were not trained. The present ratio of technical supporting manpower to engineering graduates is still quite high at about five to one, but the trend is downwards and the danger signals are evident enough.

The new Institute of Manpower Studies will be faced with considerable problems, not least in defining the nature of its own investigations. As Lord Jackson pointed out, the Committee for Manpower Resources has been unable to assess the manpower needs of the country independently of the demand from employers, which may well prove a very inaccurate guide. The new institute will have to take a more intimate look at the anatomy of the manpower situation, he said, from the point of view both of usage and of the skills required for particular jobs.
What is the long term remedy to the problem of engineering manpower? Lord Jackson saw this as part of a wider question affecting the educational system as a whole. The fundamental problem is that many science teachers have a poor knowledge of technology, and science students are too often left unaware of the technological implications of their subject. He felt that science should be taught from the outset with a greater emphasis on its relevance to technology. He also had some thoughts for the arts pupil. "The highly specialized character of sixth forms forces many pupils

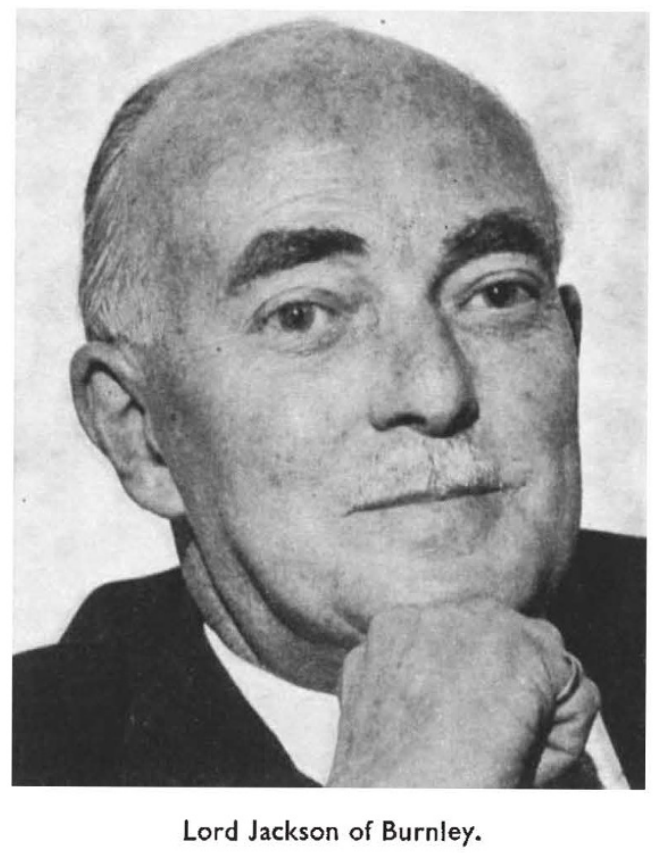

to withdraw totally from science at an early age. This is very harmful. I would like to see the emergence of a new breed of graduate, who would be a sociologist, lawyer or economist with a substantial scientific background."

Mr Edward Short, Secretary of State for Education and Science, who was chairman of the meeting, put a different gloss on engineering at the universities. $\mathrm{He}$ thought that universities should be a bit like ivory towers, but that they should always be aware of and responsive to what went on on the shop floor.

\section{CITY UNIVERSITY}

\section{Industrialized Academics}

In the three years since it was created out of the Northampton College of Advanced Technology, the City University has managed both to expand its own research activities and to build up an impressive number of projects backed by industrial money, ranging from a study of the hydrology of rivers flowing into Morecambe Bay to methods for detecting flaws in metals by ultrasonic pulses. Much of this work was to be seen on the open days held last week. There also seems to be incrcasing cooperation with other national and industrial research establishments.

An investigation of the aerodynamics of the human body by Professor R. N. Cox of the department of aeronautics illustrates particularly well the benefits of 